\title{
HIGH-RESOLUTION MONITORING OF YOK BALUM CAVE, BELIZE: AN INVESTIGATION OF SEASONAL VENTILATION REGIMES AND THE ATMOSPHERIC AND DRIP-FLOW RESPONSE TO A LOCAL EARTHQUAKE
}

\author{
Harriet E. Ridley ${ }^{*}$, James U.L. Baldini ${ }^{1}$, Keith M. Prufer ${ }^{2}$, Izabela W. WalczaK ${ }^{1}$, and \\ Sebastian F.M. Breitenbach ${ }^{3}$
}

\begin{abstract}
The nature of cave ventilation is of interest to cavers, speleologists, and paleoclimatologists working with stalagmites. Because cave ventilation systematics may change over the growth span of a stalagmite, understanding what factors affect them is critical for determining events that may have affected climate proxies within the stalagmite. Similarly, understanding how the hydrology of the drips feeding a stalagmite evolves through time is key to building robust records of paleoclimate, particularly because stalagmite records have become critical archives of climate change information of the last 500,000 years. Here we present data from an extensive, on-going monitoring effort at Yok Balum Cave, Belize, initiated in 2011, that characterizes high-resolution ventilation dynamics at this site. Clear seasonal ventilation regimes exist, driven by thermally induced inside-outside air density differences. The winter regime is dominated by air inflow into the cave, decreased drawdown from the epikarst into the cave, and a limited diurnal signal. Conversely, summer ventilation is dominated by air outflow from the cave, greater $\mathrm{CO}_{2}$ drawdown and drip water degassing, and a strong diurnal signal. Active monitoring during a large (M7.4) earthquake in November 2012 provides a unique opportunity to assess the response of the cave atmosphere and hydrology to substantial seismic activity. Cave atmosphere dynamics and hydrology are found to be highly resilient to seismic activity, with no observable disturbance occurring around the earthquake, despite there being considerable evidence of physical disruption in the cave. Monitoring included different kinds of drips, and the earthquake affected none of the monitored drip types. This suggests that stalagmite-derived paleoclimate records are not affected by seismic activity, except in extreme cases where the stalagmite or conjugate stalactite is damaged or reoriented.
\end{abstract}

\section{INTRODUCTION}

Characterizing caves in terms of their unique ventilation processes is important, as it has a first-order control on atmosphere composition, can potentially lead to seasonal bias in speleothem growth; and consequently, has significant implications when interpreting paleoclimate proxy signals from speleothems (Kowalczk and Froelich, 2010; Baldini, 2010; Sanchez-Canete et al., 2013). Cave atmosphere data are also useful when characterizing cave ecosystems (Oh and Kim, 2011; De Freitas et al., 1982) and assessing the suitability of caves for industry and tourism (De Freitas et al., 1982; Smithson, 1991; Dueñas et al., 1999; Dueñas et al., 2011; Virk et al., 1997). Estimation of cave ventilation is possible directly via anemometers, indirectly via measurement of levels of radon gas $\left({ }^{222} \mathrm{Rn}\right)$ (Kowalczk and Froelich, 2010; Hakl et al., 1997; Faimon et al., 2006; Oh and Kim, 2011) and other tracer gases (De Freitas et al., 1982), or by studies of air density contrasts and thermal patterns within the cave (Faimon et al., 2012; Smithson, 1991; SanchezCanete et al., 2013). The importance of understanding specific cave ventilation mechanisms has been well highlighted in recent studies (Kowalczk and Froelich, 2010; Cowan et al., 2013; Mattey et al., 2010; Baker et al., 2014), as the distinct nature of ventilation in individual caves can negate general assumptions regarding the seasonality of carbonate precipitation. For example, Mattey et al. (2010) identified unusual seasonal ventilation regimes in New St. Michaels Cave, Gibraltar, where the summer season was typified by low cave-air $p \mathrm{CO}_{2}$. This proved important when linking seasonal regimes to calcite fabric, paired annual laminae, and stable isotope and trace element variability, and highlighted the importance of understanding particular cave environments. Studies like this become increasingly important as speleothem-based paleoclimate

\footnotetext{
* Corresponding author: h.e.ridley@durham.ac.uk

${ }^{1}$ Department of Earth Sciences, University of Durham, Durham, DH1 3LE, UK

${ }^{2}$ Department of Anthropology, University of New Mexico, Albuquerque, NM 87106, USA.

${ }^{3}$ Department of Earth Science, University of Cambridge, Cambridge, CB2 3EQ, UK.
}

Journal of Cave and Karst Studies, December 2015 • 183 

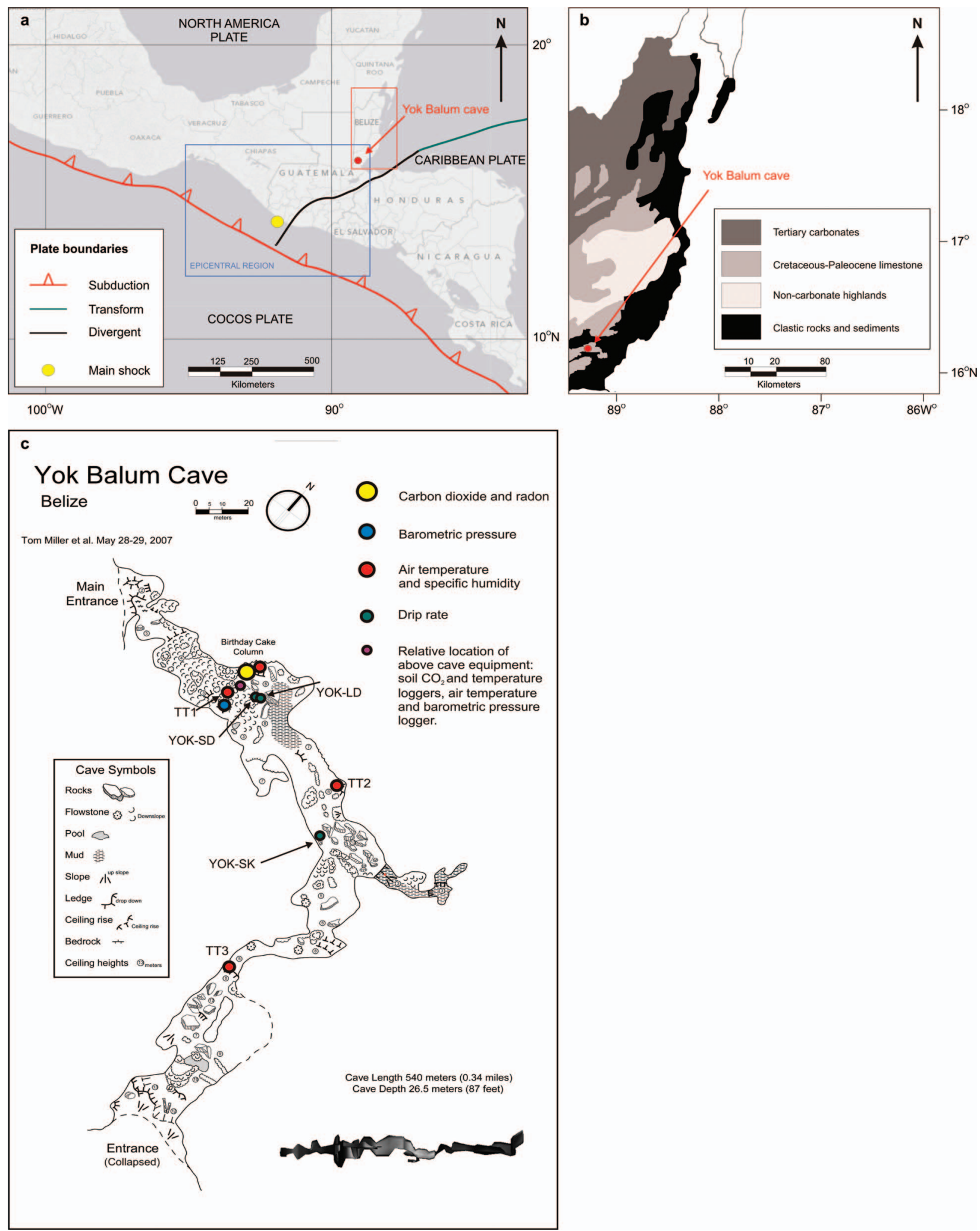

Figure 1. (a) Tectonic setting of Belize region, including tectonic boundaries (adapted from the U. S. Geological Survey). Estimated epicenter (yellow dot) and epicentral region (blue rectangle) of 7th November 2012 earthquake. Red box identifies Belize, Yok Balum Cave (red dot) and the area covered in (b), which is a geological schematic of Belize (adapted from Miller, 1996) with the location of Yok Balum Cave (red dot). (c) Map of Yok Balum Cave with equipment locations and drip sites monitored in this study. 
research continues to develop higher-resolution records that are resolved to a seasonal or sub-seasonal level.

Caves in seismically active regions can display considerable evidence of past seismic activity, such as broken speleothems, speleothem growth anomalies and deformation, displacement, and rock-fall events (Becker et al., 2006; Gilli, 1999; Gilli and Serface, 1999; Gilli and Delange, 2001). A limited number of studies have attempted to quantify the effect seismic activity may have on the atmosphere in a karst cave (Sebela et al., 2010; Virk et al., 1997), particularly with regard to $\mathrm{CO}_{2}$ variability. Such information is pertinent when interpreting proxy paleoclimate evidence from speleothems in caves that may have been subject to substantial tectonic activity, as seismic activity affects cave ${ }^{222} \mathrm{Rn}$ and $\mathrm{CO}_{2}$ levels through pro-/co-seismic degassing and increased influx to the cave (Sebela et al., 2010; Wu et al., 2003; Virk et al., 1997; Menichetti, 2013). Crushing of material during seismic activity increases the rock's permeability for ${ }^{222} \mathrm{Rn}$ gas and $\mathrm{CO}_{2}$, leading to higher in-cave concentrations. Caveair $p \mathrm{CO}_{2}$ levels exert a strong control on carbonate-precipitation rates (Baldini, 2010; Kowalczk et al., 2008; Palmer, 2007; Banner et al., 2007); and therefore, substantial crustal degassing has the potential to stagnate speleothem growth, particularly in deep, poorly ventilated passages. This can complicate paleoclimate-proxy interpretations from speleothems for weeks to years, depending on sitespecific ventilation regimes. ${ }^{222} \mathrm{Rn}$ is a radioactive yet inert tracer gas frequently used to assess cave ventilation (Kowalczk and Froelich, 2010; Oh and Kim, 2011), but it can also pose a health risk in confined, poorly ventilated caves (Field, 2007; Virk et al., 1997); therefore, its relation to seismic activity warrants assessment, particularly in caves used for commercial or tourism purposes. It is also largely unknown how seismic activity may affect karst hydrology and stalagmite-drip regimes. Changes in the hydrological regime feeding a stalagmite can affect speleothem growth rates and the transmission of geochemical signals from overlying climate to the speleothem carbonate; consequently, changes in hydrology can have important implications when interpreting paleoclimate-proxy data in speleothems.

This study presents high-resolution cave monitoring data from Yok Balum Cave, Belize. These data provide detailed information regarding seasonal cave ventilation mechanisms by demonstrating cave $p \mathrm{CO}_{2}$ and air density relationships and examination of thermal gradients as evidence of internal-external air exchange. An understanding of the subtle seasonally variable fluxes of cave air $\mathrm{CO}_{2}$ allows improved interpretations from not only Yok Balum, but also other tropical sites. Additionally, active monitoring during a large (M7.4) earthquake in November 2012 provides a unique opportunity to assess the response of cave atmosphere and hydrology to substantial seismic activity.

\section{Study Site}

Yok Balum Cave (Mopan Mayan for Jaguar Paw Cave) is located in the Toledo District of southern Belize, approximately $3 \mathrm{~km}$ south of the modern Mopan Maya village of Santa Cruz ( $16^{\circ} 12^{\prime} 30^{\prime \prime}$ N, 89 $9^{\prime} 24^{\prime \prime}$ W; 366 m above sea level) (Fig. 1a). The cave is developed within the tectonically uplifted Cretaceous Campur Limestone formation that originated from massive limestone deposition around the granite intrusions composing the Maya Mountains to the north (Miller, 1996; Kennett et al., 2012). The cave is one of several that occur in a southwest-to-northeast-trending limestonekarst ridge (Fig. 1b), and its formation was likely associated with the vertical flow of chemically aggressive allogenic water originating on the highlands of the Maya Mountains (Miller, 1996), although no stream exits within the cave today. Yok Balum extends approximately $540 \mathrm{~m}$ as a main trunk passage from a small opening in the west, the main entrance, to a larger, more elevated opening to the south, the second entrance (Fig. 1c). The second entrance resulted from cave collapse probably associated with tectonic activity. U-series dating of the base of a stalagmite growing on a breakdown block associated with the creation of the second entrance dates the collapse at a minimum of $44,000 \pm 3300$ years BP. There is also considerable evidence of seismic activity within the cave, including large faulted flowstones and displaced speleothems. U-series dating of carbonate precipitated within a faulted flowstone provided a date of $26,400 \pm 170$ years BP.

The western coast of Central America displays relatively high seismic-hazard potential due to the subduction of the Cocos Plate beneath the North American and Caribbean Plates (Fig. 1a). A divergent boundary exists between the North American and Caribbean Plates approximately 100 $\mathrm{km}$ south of the southern Belize border. The dominant source of seismic activity felt in southern Belize, however, results from intermediate depth earthquakes occurring within the subducted Cocos Plate.

\section{MONITORING INSTRUMENTATION}

Tropical environments provide a challenging environment for electronic monitoring instrumentation, especially for long term monitoring studies in remote areas. In this study, the threat of malfunction due to high humidity and water was minimized by keeping non-waterproof equipment in airtight boxes and sealed plastic bags with a silica desiccant where applicable. Above-cave soil temperature was recorded hourly using a Tiny tag temperature logger buried at a $0.4 \mathrm{~m}$ depth. Cave-air $\mathrm{CO}_{2}$ was monitored every three hours between April 2011 and January 2013 (with a four month break from June 2012 to October 2012 due to equipment failure) using a Vaisala Carbocap carbon-dioxide probe DMP343 ( \pm 3 ppmv $+1 \%$ of reading) linked to a Vaisala MI70 indicator and powered by two Duracell MN918 lantern batteries. A Radon Scout Plus, powered by two D-cell batteries and a four-D-cell external battery pack was 
Table 1. Summary of equipment used in this study, including equipment accuracy, sampling interval, and additional comments.

\begin{tabular}{|c|c|c|c|c|}
\hline Parameter & Equipment & Accuracy & $\begin{array}{l}\text { Monitoring } \\
\text { Interval }\end{array}$ & Comment \\
\hline Cave Air $\mathrm{CO}_{2}$ & $\begin{array}{l}\text { Vaisala CARBOCAP Carbon } \\
\text { Dioxide GMP343 Probe with } \\
\text { Vaisala MI70 Indicator (plus } \\
\text { two Duracell MN918 Lantern } \\
\text { batteries) }\end{array}$ & $\begin{array}{l} \pm 3 \mathrm{ppmv} \\
\pm 1 \% \text { of } \\
\text { reading }\end{array}$ & Three-Hourly & Tested upon installation. \\
\hline Temperature & Tinytag Logger & $\pm 0.1^{\circ} \mathrm{C}$ & Hourly & $\begin{array}{l}\text { Data compared to Barotoll } \\
\text { temperature data. }\end{array}$ \\
\hline${ }^{222} \mathrm{Rn}$ & $\begin{array}{l}\text { Radon Scout Plus (plus } 4 \times \text { D-cell } \\
\text { External battery pack) }\end{array}$ & $\cdots$ & Three-Hourly & $\begin{array}{l}\text { Ten days of data discarded } \\
\text { after data download due } \\
\text { to anomalously high } \\
{ }^{222} \mathrm{Rn} \text { counts after } \\
\text { opening the box. }\end{array}$ \\
\hline $\begin{array}{l}\text { Pressure and } \\
\text { Temperature }\end{array}$ & Barotroll & $\pm 0.1 \%$ & Hourly & $\begin{array}{l}\text { Data compared to Tinytag } \\
\text { temperature data. }\end{array}$ \\
\hline Rainfall & Pluvimate Rain Gauge & $\pm 0.01 \mathrm{~mm}$ & Hourly & $\begin{array}{l}\text { Located at Santa Cruz } \\
\text { village. }\end{array}$ \\
\hline Drip Rate & Stalagmate Drip Logger & $\cdots$ & Hourly & Tested upon installation. \\
\hline
\end{tabular}

set up next to the within-cave $\mathrm{CO}_{2}$ logger to measure radon fluctuations every three hours for the same time interval. The Radon Scout, being extremely sensitive to moisture, was kept in a watertight box. This resulted in a muted radon measurement, because fewer $\alpha$ particles reached the alpha counter. For qualitative assessment of ${ }^{222} \mathrm{Rn}$ fluctuations this was not considered an issue. However, ${ }^{222} \mathrm{Rn}$ values peaked following a data download when the logger was removed from the box. To account for this, ten days of data were removed after each data download to allow ${ }^{222} \mathrm{Rn}$ values to return to normal levels. Combined Barotroll pressure and temperature loggers were installed both inside and above the length of the cave to measure hourly barometric pressure and temperature (precision $\pm 0.1 \%$ and $\pm 0.1^{\circ} \mathrm{C}$ ). Tinytag temperature loggers were placed in transect along the cave to measure hourly temperature. Stalagmate automated drip-loggers recorded hourly rates of drips feeding three stalagmites of potential paleoclimate interest. Data were downloaded and the equipment maintained every four months. A summary of all monitoring equipment is shown in Table 1. The location of all equipment and monitored stalagmites is shown in Figure 1c.

\section{Cave Ventilation}

Cave ventilation (air exchange with the outside atmosphere) has a first-order control on cave atmosphere composition and is dependent on a number of factors, including fluctuations in temperature and pressure, cave geometry, and susceptibility to external winds (Cowan et al., 2013; Bourges et al., 2001; Spötl et al., 2005; Baldini et al., 2006; Denis et al., 2005; Kowalczk and Froelich, 2010). Pflitsch and Piasecki (2003) classify cave passages in terms of air movement as being dynamic, transitional, or static. However, the static state is very rarely observed, aside from in deep passages (Pflitsch and Piaseki, 2003; Przylibski and Ciezkowski, 1999). Convective air circulation, driven by internal versus external air density differences, is a dominant ventilation mechanism in caves with more than one entrance at different elevations (Gregoric et al., 2013; Kowalczk and Froelich, 2010; Wigley, 1967; Badino, 2010). In tropical caves, where cave air temperatures do not vary significantly on seasonal timescales, air density differences will be predominantly controlled by surface temperature and barometric-pressure variations (Fairchild et al., 2006). Air density responds primarily to temperature (Faimon et al., 2012; Gregoric et al., 2013; Gregoric et al., 2011) and to a lesser extent pressure and humidity as expressed in Equation (1) below (after Kowalczk (2009)):

$$
\rho_{\text {air }}=\frac{P}{R_{d} T_{\mathrm{v}}}
$$

where $R_{\mathrm{d}}$ is the universal gas constant and $P$ is barometric pressure in mb. $T_{\mathrm{v}}$ is virtual temperature, calculated via Equation (2), in which both $T$ and dew point $T_{\mathrm{d}}$ are in $\mathrm{K}$.

$$
T_{\mathrm{V}}=\frac{T+237.15}{1-0.379\left(\frac{6.11 \times 10^{\frac{7.5 \mathrm{~T}_{\mathrm{d}}}{237.3+\mathrm{T}_{\mathrm{d}}}}}{P}\right)}
$$

If cave $p \mathrm{CO}_{2}$ is more than an order of magnitude greater than that of the free atmosphere, $T_{\mathrm{v}}$ is affected. This can lead to errors of up to $9^{\circ} \mathrm{C}$ when calculating cave $T_{\mathrm{v}}$ (Sanchez-Canete et al., 2013), and consequently, errors in air density calculations. At Yok Balum the maximum recorded $p \mathrm{CO}_{2}$ is $770 \mathrm{ppm}$ and the summertime mean is $\sim 500 \mathrm{ppm}$. This is less than an order of magnitude greater 


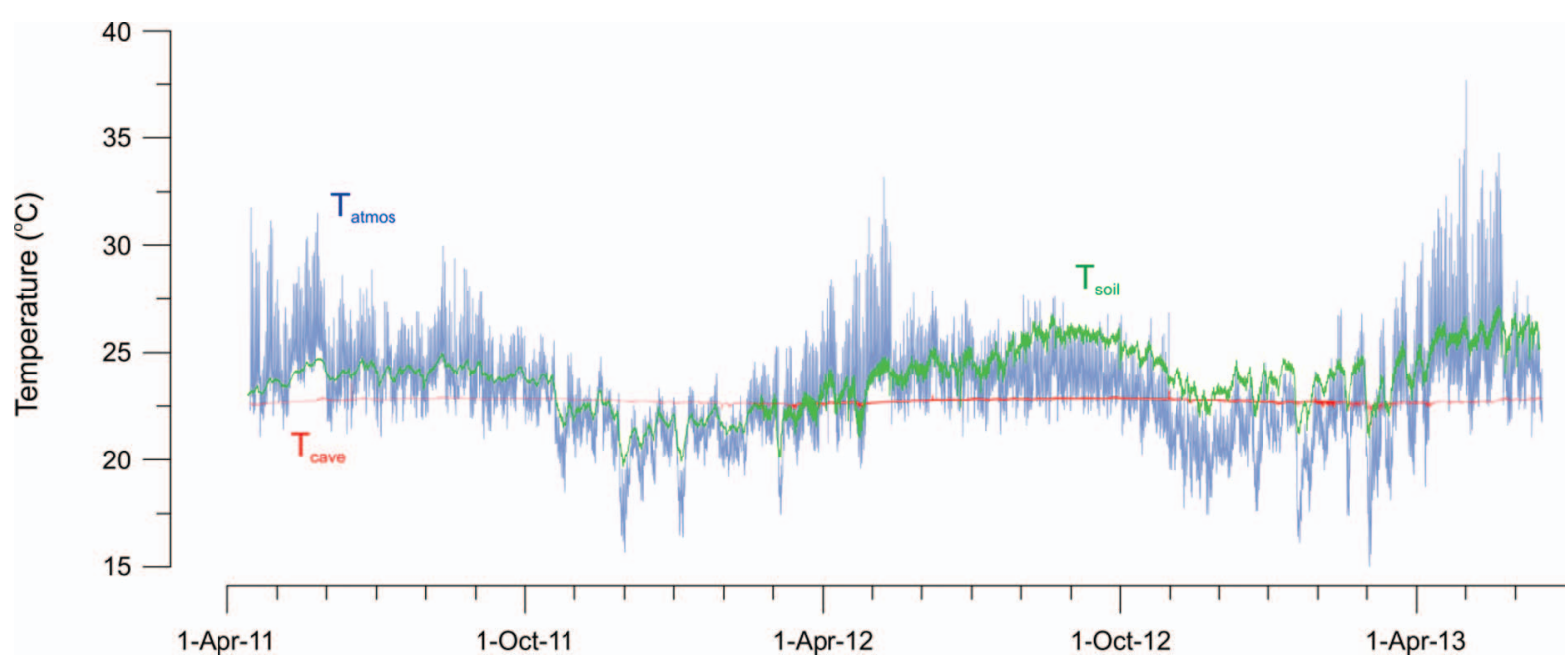

Figure 2. Time series for $\mathbf{2 6 . 5}$ months of hourly cave temperature ( $\left.T_{\text {cave }}\right)$ (using the Barotroll logger), soil temperature $\left(T_{\text {soil }}\right)$ (measured using a TinyTag), and outside air temperature $\left(\mathrm{T}_{\text {atmos }}\right)$ (using the Barotroll logger).

than the free atmosphere; and therefore, this $\mathrm{CO}_{2}$ exerts a negligible effect on cave air density.

Typically, during the winter months external air temperature will be cooler than that of the cave and a positive air density difference will dominate, i.e, external air will be denser, although a diurnal signal will also exist. Alternatively, during the summer typically warmer external temperatures will result in largely negative air density differences. Local weather may result in short-lived reversals in cave/atmosphere air density differences. The particular ventilation influence of seasonal air density differences between cave and free atmosphere is governed by the cave geometry (e.g., passage orientation and size), the distance from cave entrances, and total cave volume (Batiot-Guilhe et al., 2007; Cowan et al., 2013).

\section{Results and Discussion of Ventilation}

The diurnal and seasonal patterns of airflow at Yok Balum are a direct response to a thermally induced disequilibrium in air density between the cave and outside air, similar to other caves (De Freitas et al., 1982; Kowalczk and Froelich, 2010). Within-cave temperature is nearly constant at $22.4^{\circ} \mathrm{C}\left( \pm 0.5^{\circ} \mathrm{C}\right)$ year-round, although a low-amplitude diurnal signal is present. Within-cave temperature is equivalent to the average yearly external temperature (Fig. 2) and is likely a result of moderation of outside temperatures by the epikarst. External air temperature can affect cave air $p \mathrm{CO}_{2}$ by both inducing density-driven ventilation associated with inside-outside air density differences (De Freitas et al., 1982) (Fig. 3a ) and by causing higher soil $p \mathrm{CO}_{2}$ by stimulating biological activity in the soil zone (Baldini et al., 2008; Bond-Lamberty and Thomson, 2010; Hess and White, 1993; Murthy et al., 2003; Sherwin and Baldini, 2011).
The simple structure of Yok Balum Cave, with two entrances at either end of a single main trunk passage, results in a well-ventilated dynamic cave system, evidenced by the low annual mean $\mathrm{CO}_{2}$ values (461ppm) (Fig. 3b). However, $\mathrm{CO}_{2}$ displays clear seasonal trends in both mean concentration and variability. Summer (April-October) is characterized by higher mean $p \mathrm{CO}_{2}(\sim 500 \mathrm{ppm})$ and high temporal variability (standard deviation of $72.5 \mathrm{ppmv}$ ) whereas winter (November-March) has lower $p \mathrm{CO}_{2}$ $(\sim 420 \mathrm{ppm})$ and displays lower temporal variability (standard deviation $24.3 \mathrm{ppmv}$ ). Here, we use the theory of entropy of curves to highlight the differences between summer and winter ventilation. Entropy (E) is a measure of variance within a dataset. It is described as the mean cumulative sum of absolute first differences of a time or spatial derivative (Denis et al., 2005; Denis and Crémoux, 2002), or specifically, in this case, the average change in $p \mathrm{CO}_{2}$ values at 3-hour intervals. Higher entropy values indicate a greater change in subsequent $p \mathrm{CO}_{2}$ measurements; and therefore, an indication of variance within subsets of the dataset. $\mathrm{CO}_{2}$ displays entropy of approximately 430 during the summer and 150 during the winter (Fig. 3b), indicating that the variance is nearly three times greater during the summer months. These trends in $p \mathrm{CO}_{2}$ mean values and variance are controlled by seasonal $\mathrm{CO}_{2}$ flux into the cave and ventilation, most likely controlled by external temperatures and infiltrating rainfall. The following sections will use high-resolution-monitoring data to describe the seasonal ventilation regimes occurring in Yok Balum. It should be noted that the summer and winter seasons are not synonymous with the wet and dry seasons.

\section{Summer Regime}

Air density differences between the cave and the free atmosphere, controlled predominantly by external 


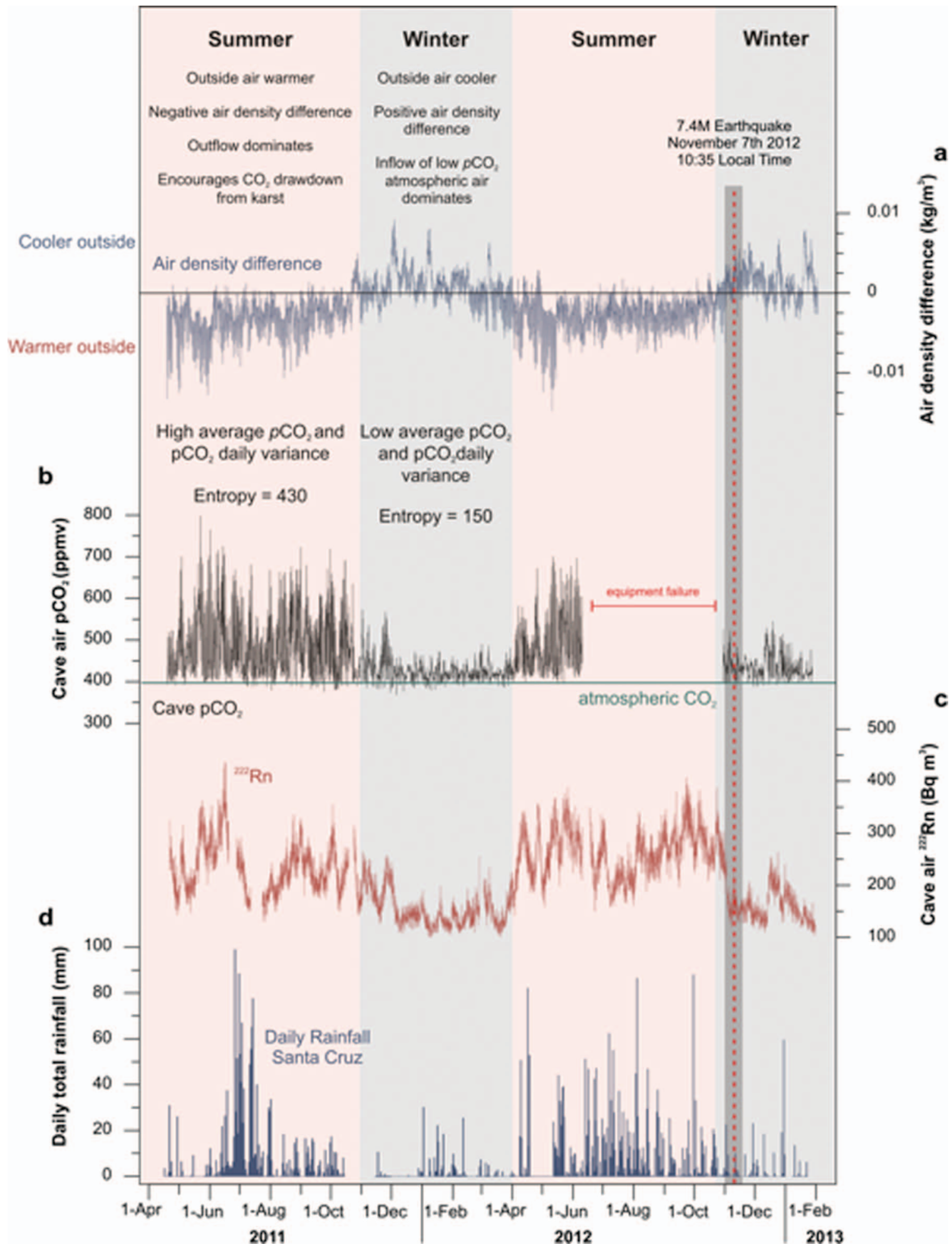

Figure 3. Seasonal regimes and dominant characteristics of (a) hourly inside versus outside air density difference. (b) Threehourly cave $p \mathrm{CO}_{2}$ and summer (April through October) and winter (December through March) $p \mathrm{CO}_{2}$ entropy values. Horizontal line at about $400 \mathrm{ppmv}$ is $\mathrm{CO}_{2}$ content of outside air, presumed constant. Three hourly ${ }^{222} \mathrm{Rn}(\mathrm{c})$ and daily rainfall at Santa Cruz (d). November 7 earthquake indicated by the red dashed line and surrounding two-week period by the gray-shaded section. 
a
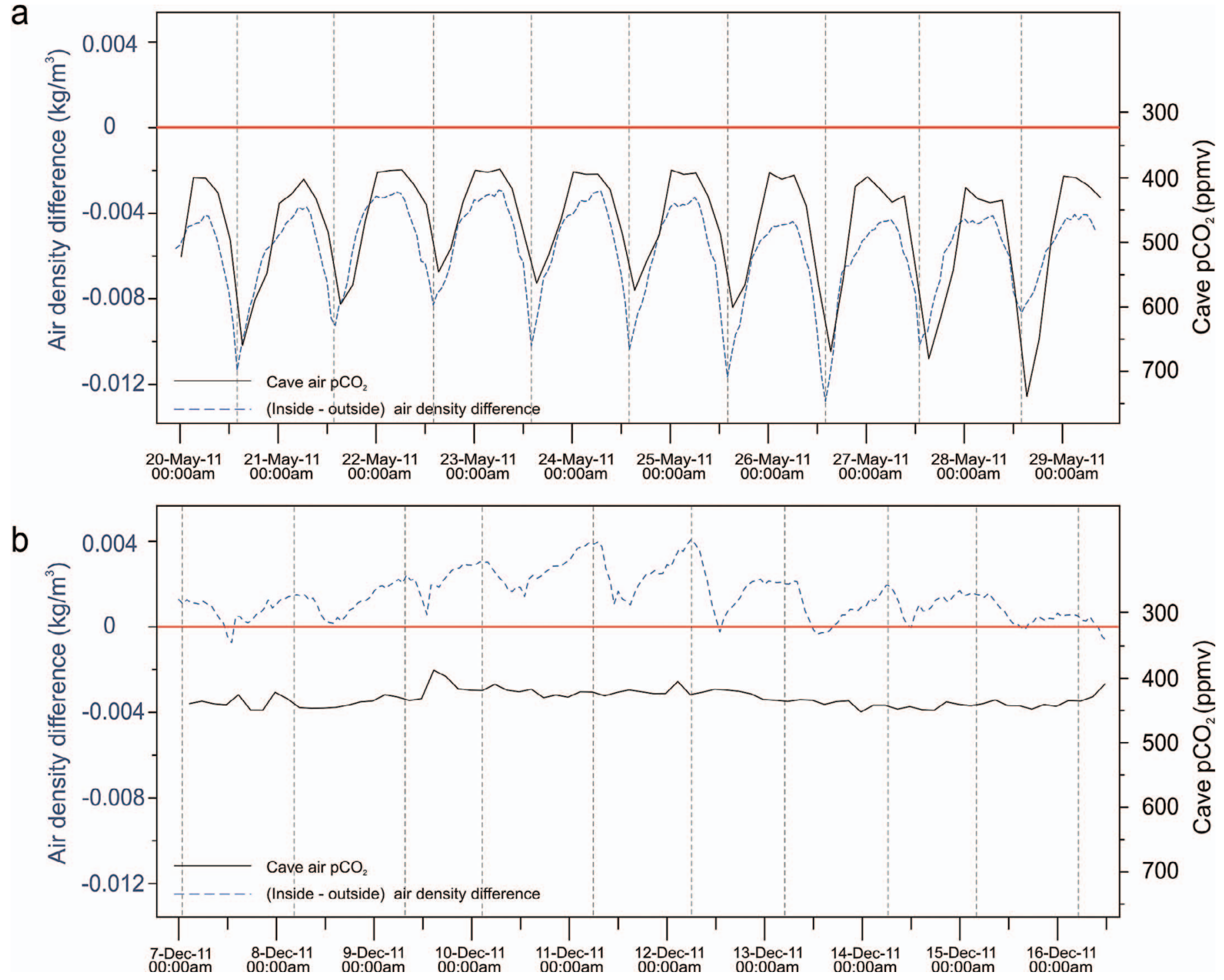

Figure 4. Hourly density difference between cave and outside air and cave $p \mathrm{CO}_{2}$ over (a) December 7-16, 2011 (winter) and (b) May 20-39, 2011 (summer).

temperature, drives the summer season diurnal ventilation regime. Outside air temperatures $\left(T_{\text {atmos }}\right)$ are higher on average than that inside the cave $\left(T_{\text {cave }}\right)$ producing an almost constant negative air density difference (Fig. 3b). In a typical one-entrance cave system this could cause severe season-long stagnation and consequently very high $p \mathrm{CO}_{2}$ as the cooler, denser cave air becomes trapped at the lowest point of elevation in the cave (Cowan et al., 2013; Spötl et al., 2005). At Yok Balum complete stagnation does not occur because the dual-entrance system provides for density-driven flow from the more elevated southern entrance to the lower western entrance.

Outside air temperature begins to rise around 0600 and reaches a maximum in the early afternoon. At this point cave/atmosphere air density difference is greatest and air outflow is at a maximum (Fig. 4a). As the air density difference increases during this period, outflow occurs at both entrances; $\mathrm{CO}_{2}$ concentrations will simultaneously increase as high $p \mathrm{CO}_{2}$ air is drawn out of the overlying epikarst and soil zones (Fig. 5a). During the day, biological activity in the soil will also be at a diurnal maximum, producing higher soil $p \mathrm{CO}_{2}$. By late afternoon the cave/atmosphere air density difference begins to decrease and the volume of outflowing air decreases, reducing $\mathrm{CO}_{2}$ drawdown from the epikarst. Outflow at the lower main entrance weakens or ceases completely. As the cave/atmosphere air density difference reaches a minimum, around 0100 , cave air $p \mathrm{CO}_{2}$ reaches minimal values. This is most likely due to minimized $\mathrm{CO}_{2}$ drawdown and inflow of low- $p \mathrm{CO}_{2}$ atmospheric air from the second entrance if $T_{\text {cave }}$ reaches or surpasses $T_{\text {atmos }}$, flushing through the cave from the second entrance to the lower main entrance (Fig. 5b). If the

Journal of Cave and Karst Studies, December 2015 189 
a

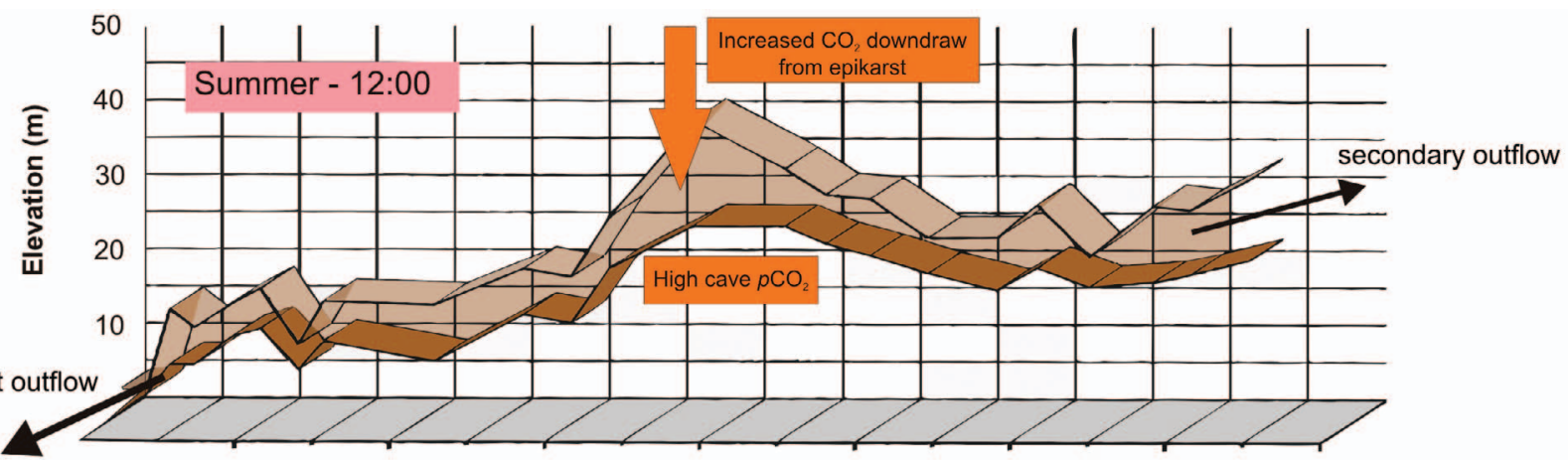

b

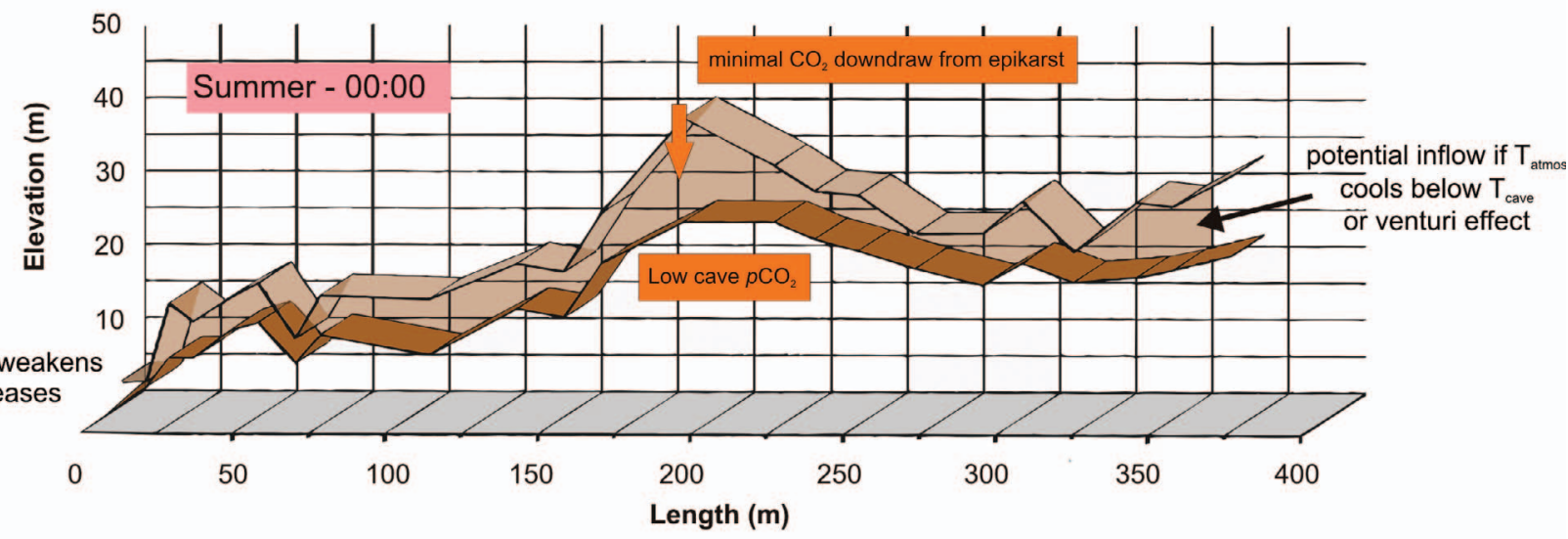

C

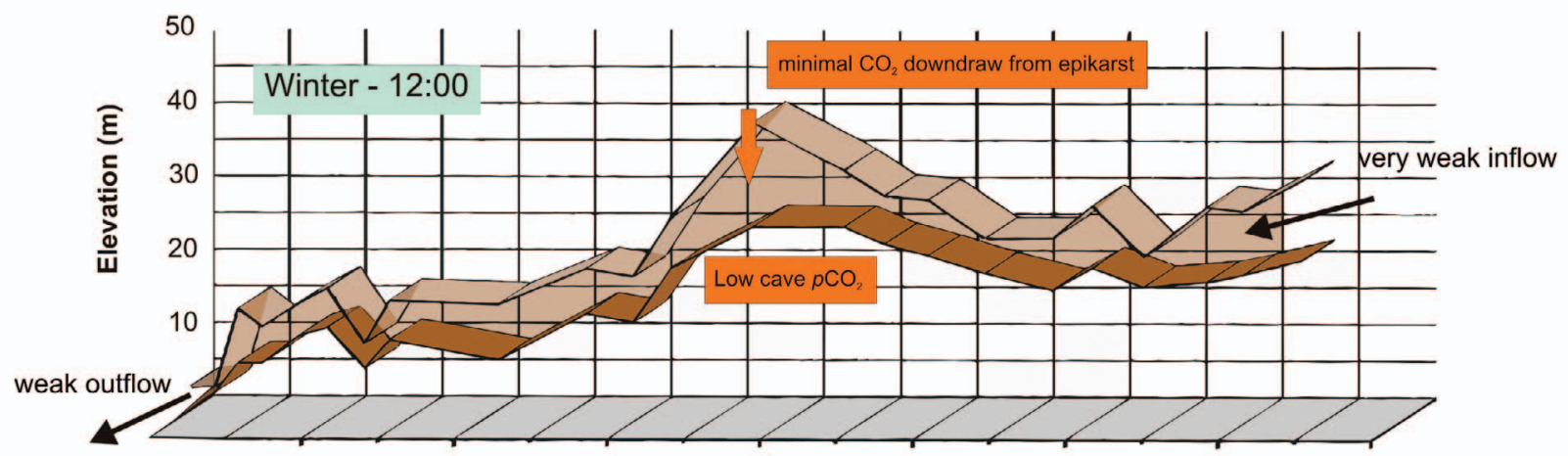

d

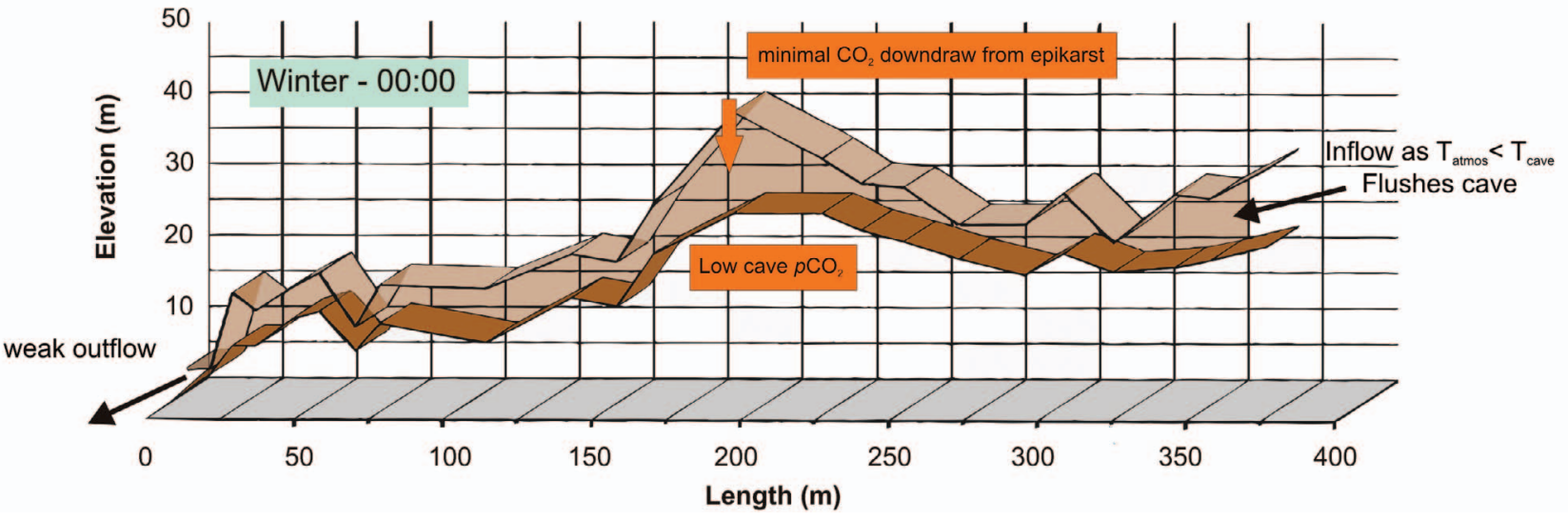

Figure 5. Yok Balum long profile with schematic of theorised primary air flows and $\mathrm{CO}_{2}$ flux during the summer at noon (a) and midnight (b). Schematic of theorised primary air flows and $\mathrm{CO}_{2}$ flux during the winter at 1200 (c) and 0000 (d). 
outside air density remains considerably higher than that of the cave, then $p \mathrm{CO}_{2}$ may remain elevated, but will decrease somewhat due to decreased $\mathrm{CO}_{2}$ drawdown from the epikarst, lower soil activity, and some air movement driven by the venturi effect (Fig. 5b). Areas closest to the entrances can be expected to undergo the most ventilation, particularly at the second entrance, which is larger. Increased water through-flow during the wet season is undoubtedly an additional driver of higher average summer $p \mathrm{CO}_{2}$, as it increases dissolved $\mathrm{CO}_{2}$ transport to the cave, increasing degassing, and consequently, producing higher cave $p \mathrm{CO}_{2}$.

\section{WINTER REGIME}

During the winter season, outside air temperatures are generally cooler than those inside the cave, producing a positive air density difference and a ventilation regime dominated by inflow. Ventilation is therefore more continuous than during the summer.

Maximum air density difference occurs at night (around 0300) when $T_{\text {atmos }}$ is at a minimum (Fig. 4b). Cooler outside air flushes into the cave, predominantly through the more elevated second entrance, but also from the main entrance. Cave-air $p \mathrm{CO}_{2}$ will therefore approximate that of the external atmosphere. Outside air temperatures begin to rise at about 0600 and reaches a maximum at about 1400, as in the summer season. However, as the outside temperature increases, it approaches that of the cave air, reducing the air density difference to near zero, or to negative values if $T_{\text {cave }}$ surpasses $T_{\text {atmos. }}$. This reduces air inflow to the cave, and if a negative air density difference occurs, then outflow may occur during this time (Fig. 5c). This variation of air density difference over a threshold value results in a daily ventilation regime whereby the cave inhales during the day and exhales at night. The inhalation during the day draws low- $p \mathrm{CO}_{2}$ air into the cave, flushing the cave and keeping $p \mathrm{CO}_{2}$ values similar to atmospheric levels (Fig. 5d). Any weak exhalation at night continues effective air turnover and maintains low $p \mathrm{CO}_{2}$ concentrations. Again, it is the areas close to the entrances that will undergo the most rigorous air turnover.

A combination of inflow-dominated ventilation and less $\mathrm{CO}_{2}$ from drip-water degassing keeps winter cave-air $p \mathrm{CO}_{2}$ at near atmospheric levels. A less distinct diurnal regime is observed in $\mathrm{CO}_{2}$ and air density difference variability. During the summer, increased water through-flow, strong air outflow and large $\mathrm{CO}_{2}$ drawdown increase average $p \mathrm{CO}_{2}$ and daily variability.

\section{Temperature Observations}

Hourly temperature data are used as an indicator of air movement to determine seasonal modes of ventilation and to understand exactly how air moves through the cave. We use Tinytag (TT) temperature loggers at different sites to assess thermal variability. TT3, a temperature logger located about $50 \mathrm{~m}$ from the second entrance, shows more variance than TTI, located about $50 \mathrm{~m}$ from the main entrance, and
TT2, located in the midsection of the cave about $100 \mathrm{~m}$ from the main entrance and about $140 \mathrm{~m}$ from the second entrance (Fig. 6e). TT2 displays the least variance and most moderated temperature (Fig. 6b). Entropy (see section 5) can be illustrated graphically through time as a cumulative curve, the slope of which indicates variability within the dataset. Entropy curves are calculated for each temperature dataset from the three loggers (Fig. 6a), thus facilitating comparison of their variance with time. TT3 displays the greatest variability over the whole time series, suggesting that this region of the cave is most strongly coupled with external air temperatures via air exchange. During the summer months TT3 increases by $0.4^{\circ} \mathrm{C}$, as air in this region responds to warmer external temperatures. TT2 is stable through the same period, and TT1 displays an increase similar to that of TT3, but of only $0.3^{\circ} \mathrm{C}$. This thermal variability decreasing with distance from a cave entrance is in accordance with a traditional cave temperature models (Wigley, 1967) and previous thermal profile studies of caves (Sanchez-Canete et al., 2013; De Freitas et al., 1982).

During the winter, TT3 displays greater variance than the other two loggers, again indicating that this section of the cave is more closely coupled to the outside air during winter than summer (Fig. 6). This is consistent with the ventilation mechanism described in the previous section, where inflow of cooler atmospheric air dominates the winter ventilation regime, simultaneously lowering long-term cave-air temperature in this area of the cave and mimicking the diurnal external temperature cycle in the cave. TT2 remains the least variable, due to its location in the midsection of the cave. TT1 decreases, indicating that cooler atmospheric air flows in, but that ventilation at the main entrance is less rigorous than at the second entrance. Furthermore, short-lived decreases in temperature recorded by TT1 (and to a lesser extent in TT2) are in anti-phase with TT3. This could be an indication of air entering at the main entrance and flushing through the cave, forcing warmer air from the less dynamic mid-section of the cave through to the second entrance, where it is recorded as a small increase in temperature at TT3. This thermal-pulse process would also operate in reverse, with cooler air entering at the second entrance and forcing air through the cave to the main entrance.

Data collected through high-resolution temperature experiments, conducted over two 14-hour intervals in June and late October 2012, are used to characterize ventilation on short time scales. A transect of three temperature loggers placed in the cave recorded temperature every 10 seconds to capture very short-term thermal fluctuations overnight, from 1800 to 0800 . Failure of one of the loggers during the June experiment limits the number of loggers to two, but does not affect data interpretation for this project. During the June experiment (Fig 8) the two temperature loggers, TT5 and TT7, record essentially static temperature, supporting the idea that air density driven outflow dominates during this season. During the logging interval, the cave air density difference does not drop below zero and so 

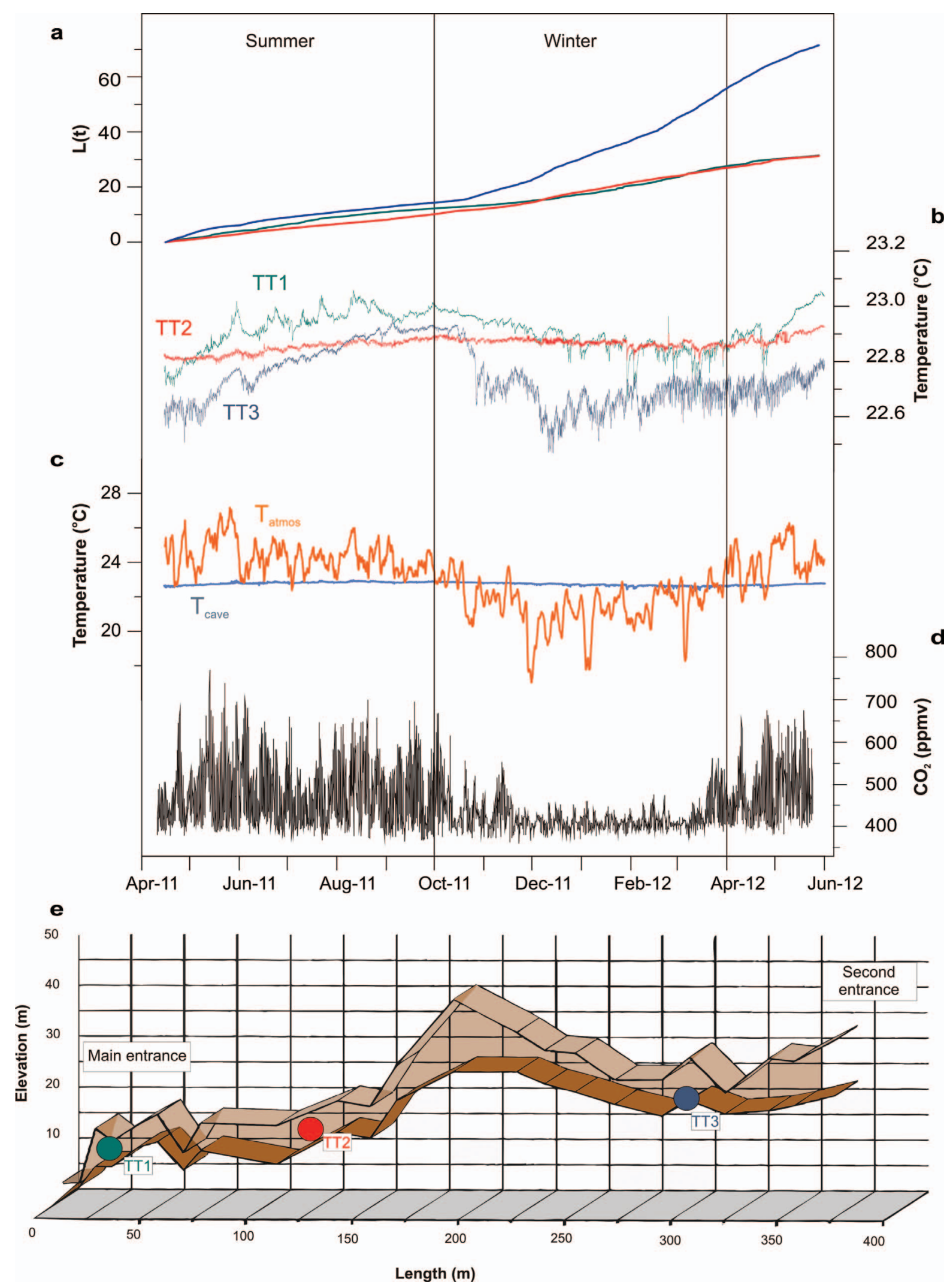

Figure 6. Time series for 14 months of (a) variability $L(t)$ of three temperature time-series expressed as entropy (cumulative sum of the absolute first differences) against time, (b) hourly temperature from the three temperature loggers in the cave, (c) hourly record of temperatures inside (TT2) and outside the cave, (d) three hourly cave air $p \mathrm{CO}_{2}$, and (e) location of temperature loggers within the cave. 

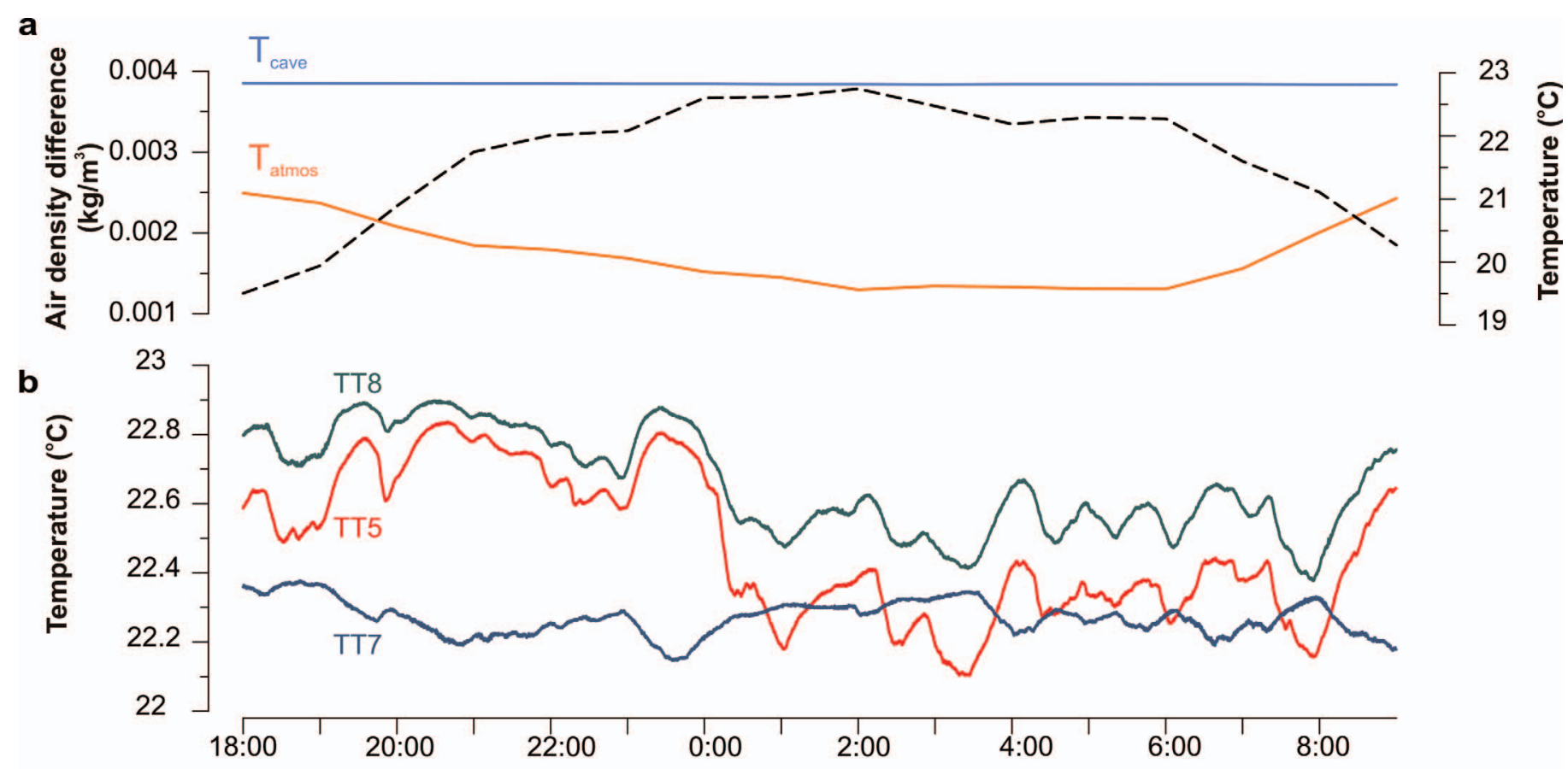

C

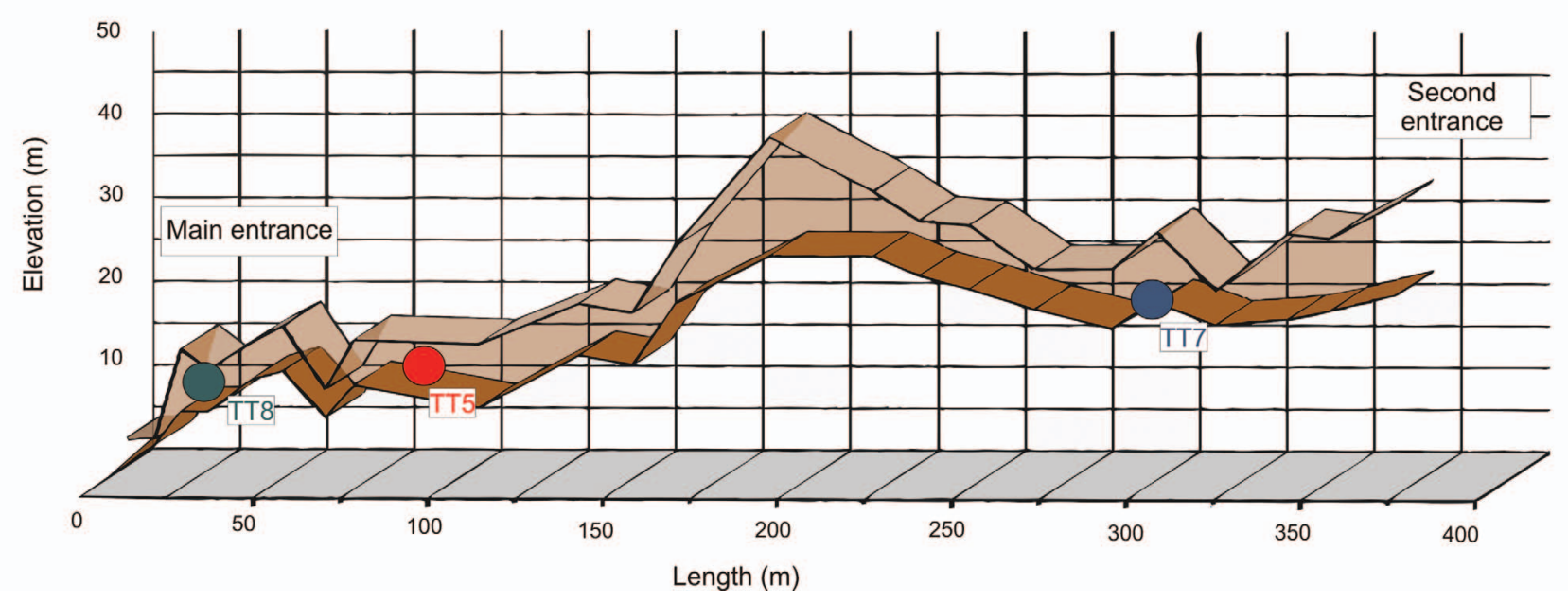

Figure 7. High-resolution winter experiment. Fourteen-hour time series of (a) hourly cave temperature, external air temperature, and internal/external air density difference and (b) 10-second temperature measurements of TT8, TT5, and TT7. (c) shows location of TT8, TT5, and TT7 in the cave.

inflow does not occur. During the late-October experiment, thermal variance at all three sites is much greater (Fig. 7). TT5 and TT8 record more thermal variability than TT7, suggesting that air inflow close to the main entrance is less persistent. TT5 and TT7 both record cooler temperatures than TT8, presumably due to their proximity to a cave entrance. TT8 and TT5 track each other, roughly in accordance with cave/atmosphere air density difference and are weakly in anti-phase with TT7. This is similar to what we see in the longer-term record (Fig. 6), where cooler external air enters the main entrance and forces air along the main passage, which is recorded as a pulse of warmer deep-cave air at the second entrance. It would appear from this high- resolution time series that this occurs in both directions. The limited temporal timeframe of these two experiments hinders making firm conclusions about the diurnal movement of air at Yok Balum Cave, but it is encouraging that the results acquired are in agreement with the longer, hourly-resolution time series.

\section{November 7 EARTHQUAKe}

On November 7, 2012, at 1635 (UTC; 1035 local time) a 7.4 magnitude earthquake struck off the coast of Guatemala (Fig. 1a). The epicentre was estimated to be at a depth of 24.0

Journal of Cave and Karst Studies, December 2015 • 193 
a

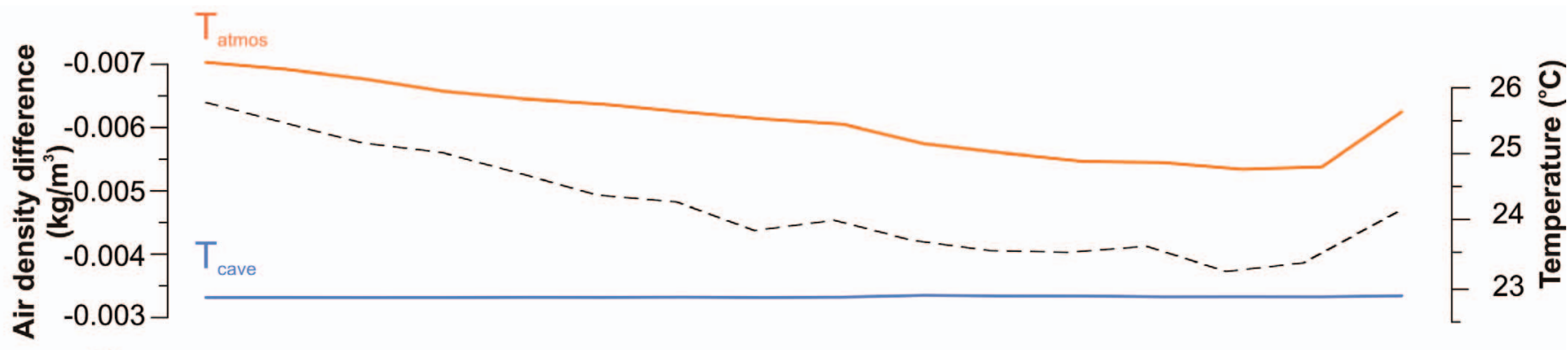

b

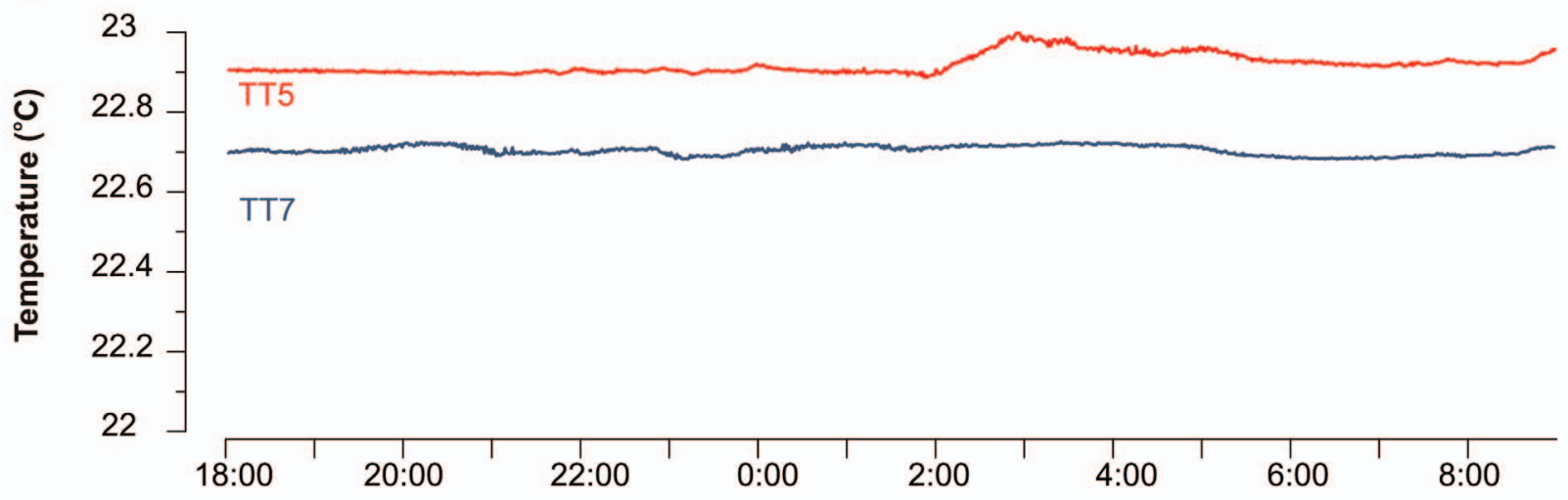

C

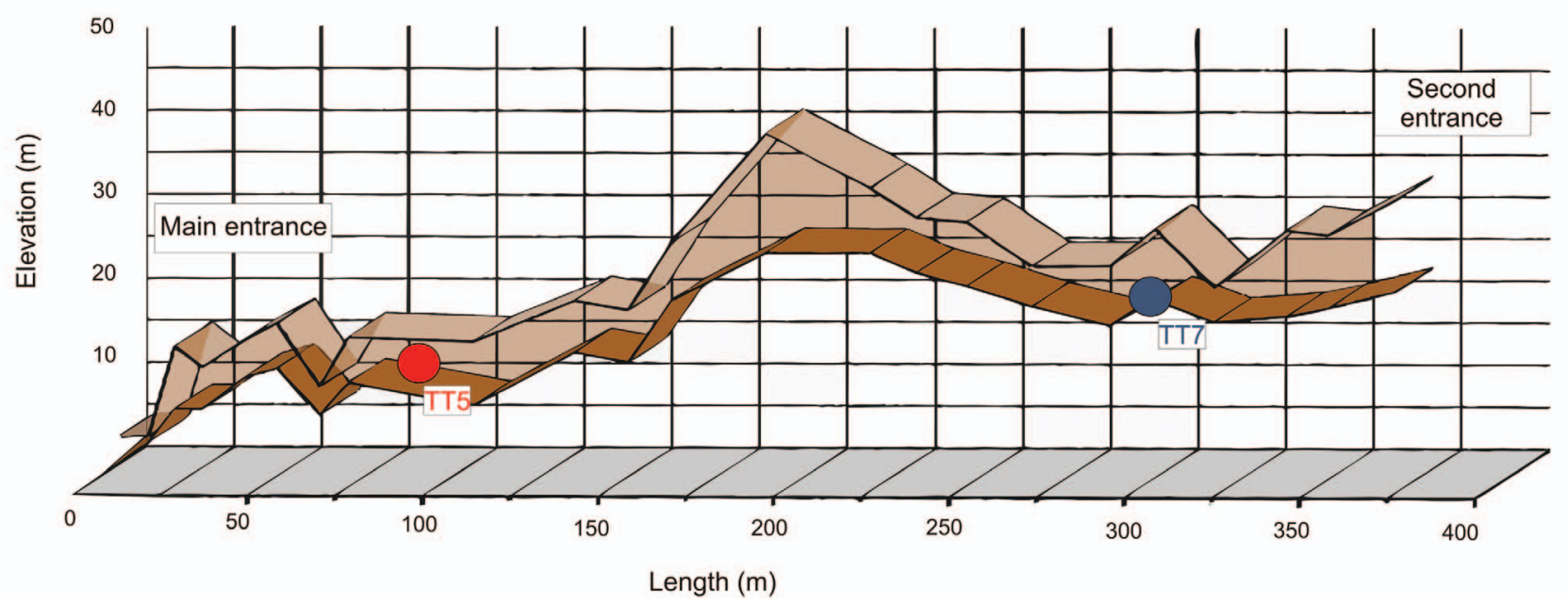

Figure 8. High-resolution summer experiment. Fourteen-hour time series of (a) hourly cave temperature (from Tinytag loggers), external air temperature, and calculated internal/external air density difference and (b) 10-second temperature measurements of TT5 and TT7. (c) shows location of TT5 and TT7 in the cave.

$\mathrm{km}$ and occurred as a result of thrust faulting on or near the subduction zone of the Cocos plate and the overlying Caribbean and North American plates. Tremors were felt in parts of Belize, and villagers from Santa Cruz village, $5 \mathrm{~km}$ from Yok Balum Cave, reported feeling the tremors. According to United States Geological Survey estimates, this shock would result in a seismic hazard, measured in peak ground acceleration at the cave site of 1.6 to $2.4 \mathrm{~m} \mathrm{~s}^{-2}$. A field crew returned to the cave in January 2013 to find large fallen blocks at the cave's main entrance and numerous displaced and freshly broken stalagmites and stalactites within the cave. Reasonable evidence therefore suggests that the cave was subject to seismic activity on or around November 7, 2012. There are only a handful of published studies reporting earthquake damage to caves (Gilli, 1999; Gilli and Delange, 2001; Renault, 1970), and so direct monitoring observations of the effect of seismic activity are pertinent to the science of speleology, in general, and have implications for reconstructing climate from cave deposits. It will be particularly useful to determine how environmental variables that affect speleothem growth and carbonate deposition, such as drip hydrology and cave ventilation, may be affected be seismic 
activity. For example, if seismic activity causes considerable water re-routing, we might expect subsequent changes in speleothem growth for days to months, which can confuse a climate record. Similarly, atypical speleothem growth or carbonate isotopes could be produced from significant seismically induced changes in cave $p \mathrm{CO}_{2}$.

\section{Cave Atmosphere Response}

No clear change occurred in cave-air $p \mathrm{CO}_{2}$ or ${ }^{222} \mathrm{Rn}$ during or for the week following the earthquake (Fig. 9). Two ${ }^{222} \mathrm{Rn}$ peaks occur around the earthquake (Fig. 9a) and although fracture dilation induced by seismic activity may cause such peaks in cave-atmosphere ${ }^{222} \mathrm{Rn}$, these peaks are not significant, in terms of magnitude or duration, when the entire ${ }^{222} \mathrm{Rn}$ dataset is considered (Fig. 3c). A sharp increase in both ${ }^{222} \mathrm{Rn}$ and $\mathrm{CO}_{2}$ occurs on December 20 (Fig. 3 b and c) but given the short half-life of radon (3.8 days) it is extremely unlikely that this is a delayed signal of the November 7 event. This increase could be explained instead by a coincident decrease in air density difference associated with a moderate rainfall event that temporarily reduced air inflow to the cave and resulted in a short-lived increase in $\mathrm{CO}_{2}$ and ${ }^{222} \mathrm{Rn}$.

A significant change in cave atmosphere may not have been observed due to the seasonal timing of the earthquake. As previously observed, cave ventilation during the winter is dominated by inflow, which acts to keep $p \mathrm{CO}_{2}$ levels low. Seismic activity of a similar magnitude occurring during the summer season, when outflow is dominant, may lead to a discernible increase in cave air ${ }^{222} \mathrm{Rn}$ and $\mathrm{CO}_{2}$. Potentially a clearer influence could be observed in a less well ventilated cave. Prior to the collapse and opening of the second entrance at Yok Balum, ventilation would have been less effective and cave air $p \mathrm{CO}_{2}$ and ${ }^{222} \mathrm{Rn}$ higher. Considerable seismic activity at that time may have created uncharacteristically high $p \mathrm{CO}_{2}$ and ${ }^{222} \mathrm{Rn}$ values as a result of limited ventilation and should be a consideration when studying speleothems from Yok Balum deposited prior to the collapse of the second entrance, when ventilation would have been restricted. Similarly, in any cave where ventilation is less efficient it may be pertinent to assess the impact of seismic activity on cave-atmospheric composition, particularly when speleothems from the cave are being considered for palaeoclimate reconstruction.

\section{Hydrological Response}

Three drip loggers were deployed during the November 2012 earthquake: YOK-SK, YOK-SD, and YOK-LD. Of these drips, two (YOK-LD and YOK-SD) were static in nature (Smart and Friederich, 1987; Baker et al., 1997), because they displayed low drip rates and low variability (Fig. 10a), indicative of a diffuse-flow-dominated hydrology. YOK-SK is classified as a seasonal drip (Baker et al., 1997), because it responds to local rainfall events and seasonal climate variability (Fig. 10a), suggesting that a fracture flow pathway is activated once a threshold rainfall rate or epikarst saturation is achieved. YOK-SK responds to local rainfall with a lag time of less than 6 days, but displays greater variability during the wet season, when the epikarst and soil are closer to saturation.

None of these three loggers recorded any clear drip response to the seismic activity on November 7 (Fig. 10b). YOK-LD and YOK-SD, the two static drips, show no response, suggesting that diffuse flow regimes are not affected by seismic activity of substantial magnitude. Similarly, YOK-SK, which at the time of the earthquake was displaying a peak in drip rate in response to rainfall events in the preceding days, shows no response outside what would be expected from the longer time series. These data suggest that preferential flow routes are not necessarily altered by seismic activity of this nature. This observation is of significant value for speleothem-based paleoclimate studies, as it suggests that seismic activity does not affect hydrological flow pathways or alter carbonate geochemistry.

\section{Conclusions}

Yok Balum is an extremely well ventilated cave system that displays distinct seasonal ventilation regimes, consistent with changes in air density differences between the cave and outside atmosphere. The winter regime is dominated by air inflow, low $p \mathrm{CO}_{2}$, and lower epikarstic drawdown and $\mathrm{CO}_{2}$ flux into the cave. Conversely, air outflow, high epikarstic $\mathrm{CO}_{2}$ drawdown, increased drip-water degassing, and a strong diurnal signal dominates the summer regime. Based on air-temperature changes, the degree of air exchange increases from the center of the cave to the entrances, and the second entrance experiences greater air exchange than the main entrance, presumably due to its size. By looking at thermal fluctuations of cave air on a ten-second timescale, the direction of air movement is identified during summer and winter nights, respectively, and both entrances are found to display active dual-directional connections to the free atmosphere. The three datasets presented here: long term three-hour $\mathrm{CO}_{2}$, hourly temperature, and the two high-resolution studies all help to build a comprehensive understanding of ventilation at Yok Balum Cave. This will be pertinent as on-going paleoclimate research at this cave. Continued monitoring will help to discern inter-annual fluctuations and identify long-term links between cave $p \mathrm{CO}_{2}$ and local climate.

Cave $p \mathrm{CO}_{2}$ and ${ }^{222} \mathrm{Rn}$ did not show any discernable response to the November 7 earthquake. Likewise, none of the three drips displayed any discernible hydrological response to the earthquake, suggesting that seismic activity, even of considerable magnitude, has minimal hydrological repercussions at Yok Balum and is insufficient to result in perturbations in speleothem petrographical or geochemical records. It is noteworthy that the three loggers recorded two end members of standard drip types, from highly

Journal of Cave and Karst Studies, December 2015 • 195 


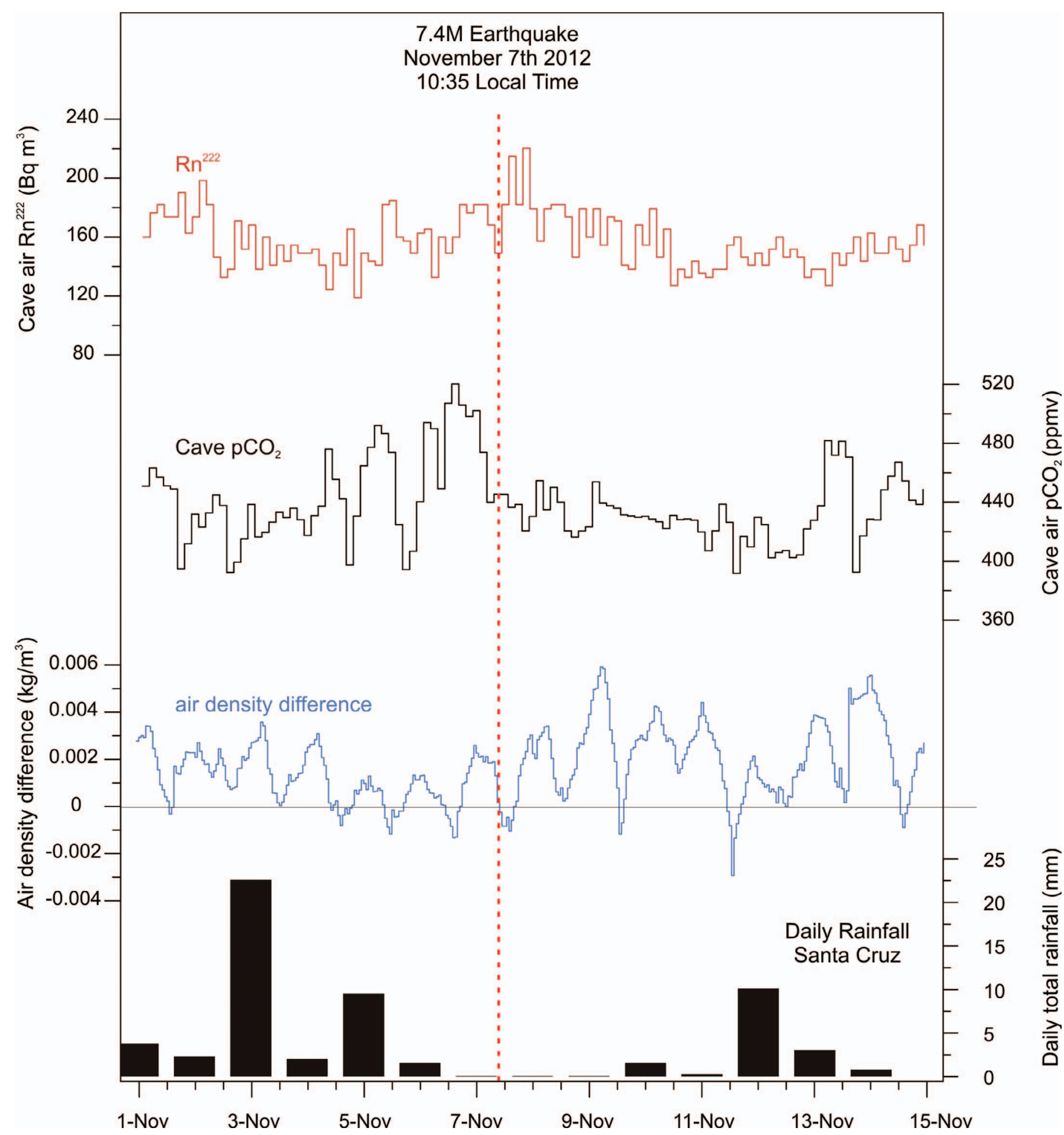

Figure 9. Traces of (a) cave-air $\mathrm{Rn}^{222}$, (b) $\mathrm{CO}_{2}$, (c) calculated inside cave versus outside air density difference, and (d) daily rainfall at Santa Cruz village during a 15-day period surrounding the November 7 earthquake (red dashed line).

diffuse, slow, and static drip rates (YOK-LD and YOKSD), to highly variable and relatively fast drip rates (YOK-SK). This suggests that intermediate drip types would probably be similarly unaffected by seismic activity of a similar magnitude. The primary effect seismic activity 196 - Journal of Cave and Karst Studies, December 2015 may have on a speleothem record is by altering the growth-axis position or orientation, rather than a direct disruption of the overlying hydrology. This could appear as a hiatus or sudden shift in isotope values if the growth axis movement was not accounted for during milling. 


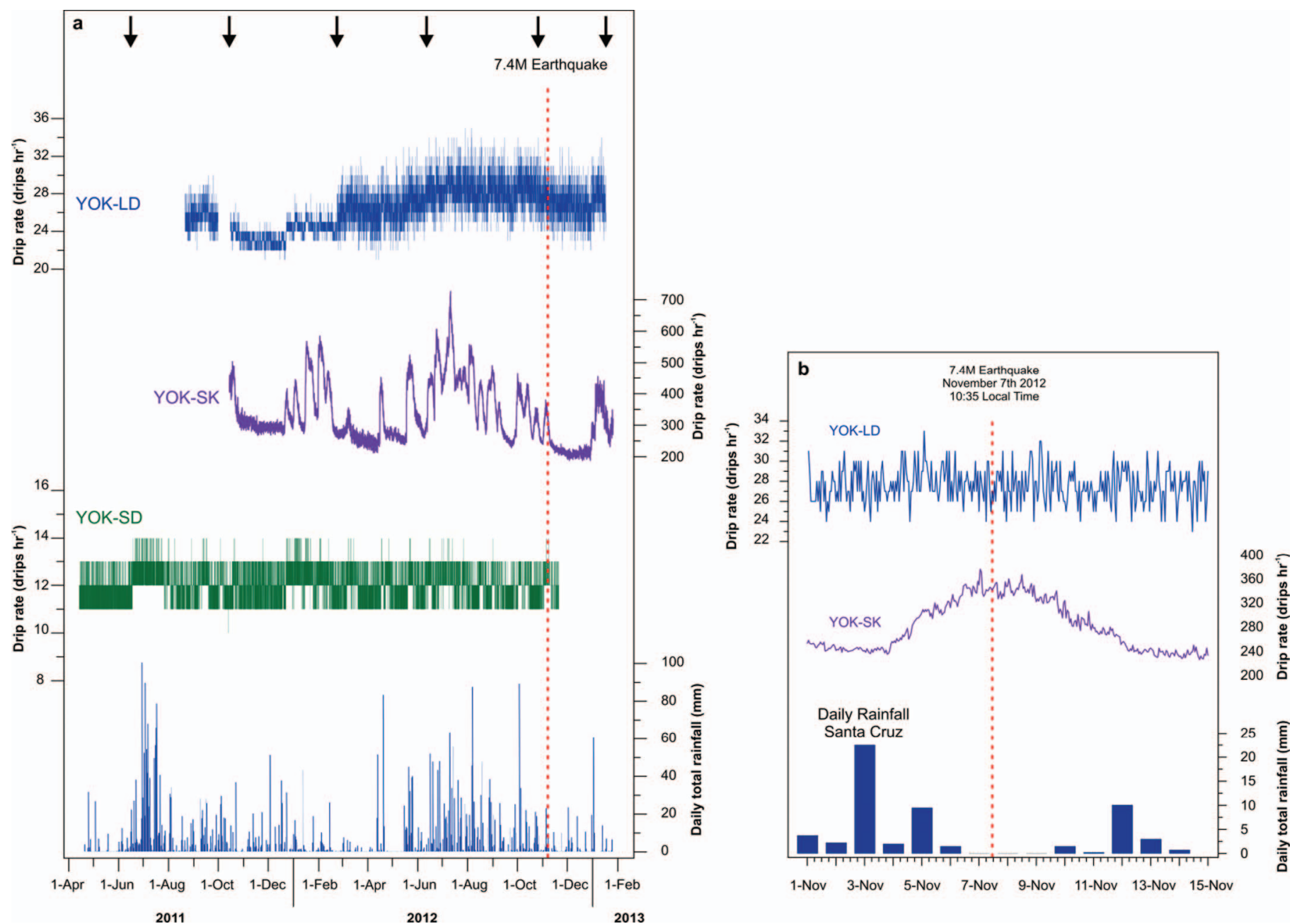

Figure 10. (a) Time series for 22 months of drip regimes of YOK-LD, YOK-SK, and YOK-SD against Santa Cruz daily rainfall; note different scales. November 7 earthquake indicated by red dashed line. Black arrows indicate visits to the cave. b) YOK-LD and YOK-SK drip- rates and Santa Cruz daily rainfall from 1 through 15 November, with time of earthquake indicated by red dashed line.

This study provides real-time data on the effect of seismic activity on cave hydrology and atmosphere. In seismically active regions, determining this site-specific response is a desirable outcome of cave monitoring studies designed to aid speleothem paleoclimate proxy interpretation. These data provide encouraging evidence that seismic activity of this level does not have implications for speleothem paleoclimate proxy interpretations from caves with similar ventilation dynamics as Yok Balum.

\section{REFERENCES}

Badino, G., 2010, Underground Meteorology - "What's the Weather Underground?": Acta Carsologica, v. 39, p. 427-448.

Baker, A., Barnes, W.L., and Smart, P.L., 1997, Variations in the discharge and organic matter content of stalagmite drip waters in Lower Cave, Bristol: Hydrological Processes, v. 11, p. 1541-1555. doi:10.1002/ (SICI)1099-1085(199709)11:11<1541::AID-HYP484>3.0.CO;2-Z.
Baker, A.J., Mattey, D.P., and Baldini, J.U.L., 2014, Reconstructing modern stalagmite growth from cave monitoring, local meteorology, and experimental measurements of dripwater films: Earth and Planetary Science Letters, v. 392, p. 239-249. doi:10.1016/j.epsl.2014. 02.036 .

Baldini, J.U.L., 2010, Cave atmosphere controls on stalagmite growth rate and paleoclimate records, in Pedley, H.M., and Rogerson, M, eds., Tufas and Speleothems: Unravelling the Microbial and Physical Controls: Geological Society London, Special Publications 336, p. 283294. doi:10.1144.SP336.15.

Baldini, J.U.L., McDermott, F., and Clipson, N., 2006, Effects of high-frequency cave atmosphere $\mathrm{P}-\mathrm{CO}_{2}$ variability on stalagmite climate proxy records [abstract]: Geochimica et Cosmochimica Acta, v. 70, p. A30A30. doi:10.1016/j.gca.2006.06.169.

Baldini, J.U.L., McDermott, F., Hoffmann, D.L., Richards, D.A., and Clipson, N., 2008, Very high-frequency and seasonal cave atmosphere $\mathrm{PCO}_{2}$ variability: Implications for stalagmite growth and oxygen isotope-based paleoclimate records: Earth and Planetary Science Letters, v. 272, p. 118-129. doi:10.1016/j.eps1.2008.04.031.

Banner, J.L., Guilfoyle. A., James, E.W., Stern, L.A., and Musgrove, M. L., 2007, Seasonal variations in modern speleothem calcite growth in Central Texas, USA: Journal of Sedimentary Research, v. 77, p. 615622. doi:10.2110/jsr.2007.065.

Journal of Cave and Karst Studies, December 2015 • 197 
Batiot-Guilhe, C., Seidel, J-L., Jourde, H., Hébrard, O, and Bailly-Comte, V., 2007, Seasonal variations of $\mathrm{CO}_{2}$ and ${ }^{222} \mathrm{Rn}$ in a mediterranean sinkhole - spring (Causse d'Aumelas, SE France): International Journal of Speleology, v. 36, p. 51-56.

Becker, A., Davenport, C.A., Eichenberger, U., Gilli, E., Jeannin, P.-Y., and Lacave, C., 2006, Speleoseismology: A critical perspective: Journal of Seismology, v. 10, p. 371-388. doi:10.1007/s10950-006-9017-z.

Bond-Lamberty, B., and Thomson, A., 2010, Temperature-associated increases in the global soil respiration record: Nature, v. 464, p. 579 582. doi:10.1038/nature08930.

Bourges, F., Mangin, A., and d'Hulst, D., 2001, Le gaz carbonique dans la dynamique de l'atmosphère des cavités karstique: l'exemple de l'Aven d'Orgnac (Ardèche): Earth and Planetary Sciences, v. 333, p. 685-692.

Cowan, B.D., Osborne, M.C., and Banner, J.L,. 2013, Temporal variability of cave-air $\mathrm{CO}_{2}$ in Central Texas: Journal of Cave and Karst Studies, v. 75, p. 38-50. doi:10.4311/2011ES0246.

De Freitas, C.R., Littlbjohn, R.N., Clarkson, T.S., and Kristament, I.S., 1982, Cave climate: Assessment of airflow and ventilation: Journal of Climatology, v. 2, p. 383-397. doi:10.1002/joc.3370020408.

Denis, A., and Crémoux, F., 2002, Using the entropy of curves to segment a time or spatial series: Mathematical Geology, v. 34, p. 899-914. doi:10.1023/A:1021302922108.

Denis, A., Lastennet, R., Huneau, F., et al., 2005, Identification of functional relationships between atmospheric pressure and $\mathrm{CO}_{2}$ in the cave of Lascaux using the concept of entropy of curves: Geophysical Research Letters, v. 32, L05810, 4 p., doi:10.1029/2004GL022226. [articles are numbered and then paged individually]

Dueñas, C., Fernández, M.C., Cañete, S., Carretero, J., and Liger, E., $1999,{ }^{222} \mathrm{Rn}$ concentrations, natural flow rate and the radiation exposure levels in the Nerja Cave: Atmospheric Environment, v. 33, p. 501-510. doi:10.1016/S1352-2310(98)00267-2.

Dueñas, C., Fernández, M.C., Cañete, S., Pérez, M., and Gordo, E., 2011, Seasonal variations of radon and the radiation exposure levels in Nerja cave, Spain: Radiation Measurements, v. 46, p. 1181-1186. doi:10.1016/j.radmeas.2011.06.039.

Faimon, J., Štelcl, J., and Sas, D., 2006, Anthropogenic $\mathrm{CO}_{2}$-flux into cave atmosphere and its environmental impact: A case study in the Císařská Cave (Moravian Karst, Czech Republic): Science of the Total Environment, v. 369, p. 231-245. doi:10.1016/j.scitotenv.2006.04.006.

Faimon, J., Troppová, D., Baldik, V., and Novotný, 2012, Air circulation and its impact on microclimatic variables in the Císařská Cave (Moravian Karst, Czech Republic): International Journal of Climatology, v. 32, p. 599-623. doi:10.1002/joc.2298.

Fairchild, I.J., Smith, C.L., Baker, A., Fuller, L., Spötl, C., Mattey, D., McDermott, F., and E.I.M.F., 2006, Modification and preservation of environmental signals in speleothems: Earth-Science Reviews, v. 75 , p. 105-153. doi:10.1016/j.earscirev.2005.08.003.

Field, M.S., 2007, Risks to cavers and cave workers from exposures to lowlevel ionizing $\alpha$ radiation from ${ }^{222} \mathrm{Rn}$ decay in caves: Journal of Cave and Karst Studies, v. 69, p. 207-228.

Gilli, E., 1999, Evidence of palaeoseismicity in a flowstone of the Observatoire cave (Monaco): Geodinamica Acta, v. 12, p. 159-168. doi:10.1080/09853111.1999.11105339.

Gilli, E., and Delange, P., 2001, Utilisation des spéleothemes comme indicateurs de néotectonique ou de la paléosismicité, in Gille, E., and Audra, P. eds., Tectonique Active et Géomorphologie, Revue d'Analyse Spatiale Quantitative et Appliquée, Special Publication 2001, p. 79-90.

Gilli, E., and Serface, R., 1999, Evidence of palaeoseismicity in the caves of Arizona and New Mexico (USA): Earth and Planetary Sciences, v. 329, p. 31-37. doi:10.1016/S1251-8050(99)80224-9.

Gregoric, A., Vaupotic, J., and Gabrovsek, F., 2013, Reasons for large fluctuation of radon and $\mathrm{CO}_{2}$ levels in a dead-end passage of a karst cave (Postojna Cave, Slovenia): Natural Hazards and Earth System Sciences, v. 13, p. 287-297.

Gregorič, A., Zidanšek, A., and Vaupotič, J., 2011, Dependence of radon levels in Postojna Cave on outside air temperature: Natural Hazards and Earth System Sciences, v. 11, p. 1523-1528. doi:10.5194/nhess11-1523-2011.

Hakl, J., Hunyadi, I., Csige, I., Géczy. G., Lénárt, L., and Várthegyi, A., 1997, Radon transport phenomena studied in karst caves - International experiences on radon levels and exposures: Radiation Measurements, v. 28, p. 675-684. doi:10.1016/S1350-4487(97)00163-7.

Hess, J.W., and White, W.B., 1993, Groundwater geochemistry of the carbonate karst aquifer, south-central Kentucky, USA: Applied Geochemistry, v. 8, p. 189-204. doi:10.1016/0883-2927(93)90034-E
Kennett, D.J., Breitenbach, S.F.M., Aquino, V.V., Asmerom, Y, Awe, J. Baldini, J.U.L., Bertlein, P., Culleton, B.J., Ebert, C., Jazwa, C., Macri, M.J., Marwan, N., Polyak, V., Prefer, K., Ridley, H.E., Sodemann, H., Winterhalder, B., and Haug, G. H., 2012, Development and disintegration of Maya political systems in response to climate change: Science, v. 338, p. 788-791. doi:10.1126/science.1226299.

Kowalczk, A., 2009, High resolution microclimate study of Hollow Ridge Cave: Relationships between cave meteorology, air chemistry, and hydrology and the impact of speleothem deposition [MS thesis]: Department of Earth, Ocean and Atmospheric Sciences, Florida State University, Thallahasse, $238 \mathrm{p}$.

Kowalczk, A., and Froelich, P., 2010, Cave air ventilation and $\mathrm{CO}_{2}$ outgassing by radon-222 modeling: How fast do caves breathe?: Earth and Planetary Science Letters, v. 289, p. 209-219. doi:10.1016/j.epsl.2009. 11.010 .

Kowalczk, A.J., Froelich, P.N., Gaffka, C., and Tremaine, D., 2008, High resolution time series cave ventilation processes and the effects on cave air chemistry and drip waters: Speleoclimatology and proxy calibration [abstract]: EOS Transactions American Geophysical Union, v. 89, fall meeting supplement, abstract PP51C-1521.

Mattey, D.P., Fairchild, I.J., Atkinson, T.C., et al., 2010, Seasonal microclimate control of calcite fabrics, stable isotopes and trace elements in modern speleothem from St Michaels Cave, Gibraltar, in Pedley, H.M., and Rogerson, M, eds., Tufas and Speleothems: Unravelling the Microbial and Physical Controls: Geological Society London, Special Publications 336, p. 323-344. doi:10.1144/ SP336.17.

Menichetti, M., 2013, Karst processes and carbon flux in the Frasassi Caves, Italy, in Filippi, M., and Bosák, P., eds, 16th International Congress of Speleology Proceedings, v. 3, p. 376-378.

Miller, T.E., 1996, Geologic and hydrologic controls on karst and cave development in Belize: Journal of Cave and Karst Studies, v. 58, p. $100-120$.

Murthy, R., Griffin, K.L., Zarnoch, S.J., Dougherty, P.M., Watson, B., Van Haren, J., Patterson, R.L., and Mahato, T., 2003, Carbon dioxide efflux from a $550 \mathrm{~m}^{3}$ soil across a range of soil temperatures: Forest Ecology and Management, v. 178, p. 311-327. doi:10.1016/S03781127(02)00480-2.

Oh, Yong Hwa, and Kim, Guebuem, 2011, Factors controlling the air ventilation of a limestone cave revealed by ${ }^{222} \mathrm{Rn}$ and ${ }^{220} \mathrm{Rn}$ tracers: Geosciences Journal, v. 15, p. 115-119. doi:10.1007/s12303011-0010-3.

Palmer, A.N., 2007, Cave geology and speleogenesis over the past 65 years: Role of the National Speleological Society in advancing the science: Journal of Cave and Karst Studies, v. 69, p. 3-12.

Pflitsch, A., and Piaseki, J., 2003, Detection of an airflow system in Niedzwiedia (Bear) Cave, Kletno, Poland.: Journal of Cave and Karst Studies, v. 65 , p. $160-173$.

Przylibski, T.A., and Ciezkowski, W., 1999, Seasonal changes of radon concentration in the Niedzwiedzia Cave (SW Poland): Nuovo Cimento Della Societa Italiana Di Fisica C-Geophysics and Space Physics, v. 22 , p. $463-469$.

Renault, P., 1970, La Eormation des Cavernes: Paris, Presses universitaires de France, $128 \mathrm{p}$.

Sánchez-Cañete, E.P., Serrano-Ortiz, P., Domingo, F., and Kowalski, A.S., 2013, Cave ventilation is influenced by variations in the $\mathrm{CO}_{2}$-dependent virtual temperature: International Journal of Speleology, v. 42, p. 1-8. doi:10.5038/1827-806X.42.1.1.

Šebela, S., Vaupotič, J., Koštak, B., and Stemberk, J., 2010, Direct measurement of present-day tectonic movement and associated radon flux in Postojna Cave, Slovenia: Journal of Cave and Karst Studies, v. 72, p. 21-34. doi:10.4311/jcks2009es0077.

Sherwin, C.M., and Baldini, J.U.L., 2011, Cave air and hydrological controls on prior calcite precipitation and stalagmite growth rates: Implications for paleoclimate reconstructions using speleothems: Geochimica et Cosmochimica Acta, v. 75, p. 3915-3929. doi:10.1016/ j.gca.2011.04.020.

Smart, P.L., and Friederich, H., 1987, Water movement and storage in the unsaturated zone of a maturely karstified carbonate aquifer, Mendip Hills, England, in Proceedings of the Environmental Problems in Karst Terranes and their Solutions Conference, October 28-30, 1986, Bowling Green, Kentucky: Dublin, Ohio, National Water Well Association, p. $59-87$. 
Smithson, P.A., 1991, Inter-relationships between cave and outside air temperatures: Theoretical and Applied Climatology, v. 44, p. 65-73. doi:10.1007/BF00865553.

Spötl, C., Fairchild, I.J., and Tooth, A.F., 2005, Cave air control on dripwater geochemistry, Obir Caves (Austria): Implications for speleothem deposition in dynamically ventilated caves: Geochimica et Cosmochimica Acta, v. 69, p. 2451-2468. doi:10.1016/j.gca.2004. 12.009 .

Virk, H.S., Singh, M., and Ramola, R.C., 1997, Radon monitoring for uranium exploration, earthquake prediction and environmental health hazard in Himachal Pradesh, India: an appraisial, in Virk, H.S., ed., Rare Gas Geochemistry - Applications in Earth and Environmental Sciences: Amritsar, Indian, Guru Nanak Dev University, p. 89-99.

Wigley, T.M.L., 1967, Non-steady flow through a porous medium and cave breathing: Journal of Geophysical Research, v. 72, p. 3199-3205. doi:10.1029/JZ072i012p03199.

Wu, Y., Wang, W., Xu, Yonhxin, Liu, H., Zhou, X., Wang, L., and Titus, R., 2003, Radon concentration: A tool for assessing the fracture network at Guanyinyan study area, China: Water SA, v. 29, p. $49-53$. 